\title{
Estuarine-terrestrial habitat gradients enhance nursery function for resident and transient fishes in the San Francisco Estuary
}

\author{
Denise D. Colombano ${ }^{1,2, *}$, Amber D. Manfree ${ }^{1}$, Teejay A. O'Rear ${ }^{1,2}$, \\ John R. Durand ${ }^{1,2}$, Peter B. Moyle ${ }^{1,2}$ \\ ${ }^{1}$ Center for Watershed Sciences, University of California, Davis, One Shields Avenue, Davis, California 95616, USA \\ ${ }^{2}$ Department of Wildlife, Fish, and Conservation Biology, University of California, Davis, One Shields Avenue, Davis, \\ California 95616, USA
}

\begin{abstract}
Nursery functions of US West Coast drowned river valley estuaries are not well understood. Using long-term fish-monitoring data (1995-2017) in Suisun Marsh, San Francisco Estuary, California, USA, we examined spatial and temporal trends in abundance and apparent growth of fishes with diverse life-history types. Focal species were Sacramento splittail Pogonichthys macrolepidotus, striped bass Morone saxatilis, tule perch Hysterocarpus traski, and starry flounder Platichthys stellatus, which collectively represented $55 \%$ of total catch $(\mathrm{n}=140092)$. We identified keystone habitat patches that functioned as nursery hotspots during the peak young-ofthe-year recruitment window. Deep, flow-through sloughs close to the open estuary were important nursery habitats for the marine transient starry flounder. In contrast, splittail and striped bass mostly migrated through such corridors to rear in shallow, dead-end sloughs transecting tidal marsh plains, managed tidal ponds, and uplands. Tule perch were concentrated in shallow, interior sloughs, reflecting their resident life-history type and adaptations to variable conditions in a small home range. Interactions among freshwater flows and stationary habitat features (e.g. channel depth, land-to-open-water ratio) were related to fish abundance; however, species and age classes differed in their relationships to these interactions, suggesting a mechanism for habitat partitioning in space and time. Overall, we inferred that habitat connectivity - longitudinal, lateral, and vertical - along the estuarine-terrestrial gradient was a driver of fish species diversity and productivity. Consideration of seascape-landscape dynamics across multiple spatial and temporal scales in estuaries should help maintain or increase fish populations and ecological resilience in the face of rising sea levels and other environmental stressors.
\end{abstract}

KEY WORDS: Fishes $\cdot$ Habitat gradients $\cdot$ Land-water interactions $\cdot$ Seascape nursery

\section{INTRODUCTION}

Understanding the drivers of nursery function for nekton is a central goal in marine ecology (Beck et al. 2001). Recent research proposes that nursery function is driven by environmental variability, hydrodynamics, trophic coupling, ontogenetic movements, and differential use of habitat patches and corridors

${ }^{*}$ Corresponding author: dpdecarion@ucdavis.edu
(Litvin et al. 2018). The notion is that complex, connected, and productive shallow-water habitats improve survival of juveniles because they allow movement among habitats that differ in food, predation refuge, or water quality or flow conditions (Beck et al. 2001, Nagelkerken et al. 2015). Understanding the natural history of juvenile fishes (e.g. ontogenetic shifts in habitat use) and how species with different

(C) The authors, University of California Davis, and Emily Damstra 2020. Open Access under Creative Commons by Attribution Licence. Use, distribution and reproduction are unrestricted. Authors and original publication must be credited.

Publisher: Inter-Research · www.int-res.com 
life histories leverage variable conditions across space and time are thus essential to developing management strategies for coastal and estuarine environments (Munsch et al. 2016).

Ecologists have historically described nurseries as areas that support substantial numbers of economically, recreationally, or ecologically significant species that depend on nearshore habitats as juveniles and then recruit to offshore marine fisheries as adults (Hay 1905, Gunter 1967, Boesch \& Turner 1984). Beck et al. (2001) developed a conceptual framework that defined nurseries as habitat patches that contribute disproportionately to the density, biomass, growth, and/or survival of juveniles to adult populations. Some examples of well-recognized nursery habitats are salt marshes, seagrass meadows, mangrove forests, and coral reefs. This seminal concept inspired ecosystem-based fishery management through protection of high-value nursery habitats similar to that of offshore marine protected areas. However, the concept does not explicitly integrate many of the dynamic processes of coastal and estuarine ecosystems (Litvin et al. 2018).

The recently proposed 'seascape nursery' concept (Nagelkerken et al. 2015) posits that nurseries encompass mosaics of coastal and estuarine habitats that are functionally linked physically and ecologically. An important advancement is that this concept explicitly incorporates dynamic patterns and processes in heterogeneous marine environments; however, critical transition zones along the land-water interface require closer investigation (Boström et al. 2011, Oleson et al. 2017). This is especially true in topographically diverse systems that have received less attention in the literature, such as drowned river valley estuaries on the US West Coast (Hughes et al. 2014). Tidal marshes are model systems for studying ecological gradients because they are complex mosaics of connected habitats and corridors that occur along a gradient of estuarine and terrestrial influences; the gradient can structure ontogenetic habitat use by juvenile nekton (Rountree \& Able 2007, Weinstein et al. 2014). To better understand drivers of nursery function using a systems approach sensu Nagelkerken et al. (2015), we related longterm fish-monitoring data to flows, water-quality conditions, and stationary habitat features in a large brackish wetland, located in a major drowned river valley estuary in California.

Our first question was: Do species exhibit temporal shifts in abundance, distribution, or growth over ontogeny? Recent research on a nearshore fish assemblage has shown that different fish types can partition habitat in both space and time (Munsch et al. 2016). Resident species, which typically spend their entire life in a given habitat/area, are adapted to frequent shifts in habitat quality in smaller home ranges, whereas transient species are highly mobile and frequently move among habitat patches in search of resources (Rountree \& Able 2007). Tradeoffs in food availability and predation risk may also play an important role in habitat selection (McIvor \& Odum 1988, Munsch et al. 2016). For example, nearshore habitats often have a lot of foodi however, the need for transient juveniles to grow may be offset by their need to occupy habitats less accessible to predators (Lankford \& Targett 1994, Sogard 1997, Dahlgren \& Eggleston 2000, Grol et al. 2011). Nevertheless, growing rapidly in risky habitats may be advantageous if it allows individuals to recruit to the next size class quickly. Larger fish may have a 'refuge in size' from predation, allowing them to occupy habitats with more food (Sogard 1997). To determine how fishes with different life histories exhibit such spatial and temporal habitat partitioning over ontogeny, we evaluated seasonal and annual trends in abundance, distribution, and apparent growth using hierarchical non-linear models.

Next, we asked: What are the relative effects of stationary habitat features, freshwater flows, and waterquality conditions on habitat use? Specifically, do land-water interactions influence nursery function? To answer these questions, we used a seascape ecology approach to characterize structural patterns among sloughs. We then used a combination of nonmetric multidimensional scaling and hierarchical linear models to compare the effects of stationary habitat variables, flows, and water quality on fish distribution and abundance. We anticipated such relationships because freshwater flows affect fish assemblages in brackish zones and because temperate estuaries exhibit seasonal shifts in prevailing environmental conditions while individuals grow. Based on these expectations, we hypothesized that species with different life histories, all of which evolved under dynamic estuarine conditions yet have different environmental tolerances/preferences, would exhibit distinct habitat associations along the estuarine-terrestrial gradient. We also looked for evidence of marsh dependence in early stages of ontogeny. We hypothesized that because juveniles must balance tradeoffs between foraging and predator avoidance, and because marshes can provide refuges from predators (Kneib 1997) while supplying food (Robertson \& Duke 1990), early life-history stages of fishes rely on marshes or other terrestrial-influenced habitats. 


\section{MATERIALS AND METHODS}

\subsection{Study system}

Surveys were conducted in Suisun Marsh, San Francisco Estuary, California, USA (Fig. 1), a 470 km² brackish wetland ecosystem located approximately $80 \mathrm{~km}$ upstream of the Golden Gate of San Francisco Bay and west of the Sacramento-San Joaquin Delta ('Delta'; Whitcraft et al. 2011). Approximately twothirds of the landscape is diked wetlands, which are managed primarily as tidal ponds for waterfowl; the remaining one-third is a network of subtidal and intertidal sloughs featuring varying levels of channel realignment, diking, infill, and ditching for mosquito control (Moyle et al. 2014). Low- to moderate-relief grasslands are hydrologically connected to Suisun
Marsh's sloughs by perennial and seasonal creeks and seeps, intermittent overland flow, groundwater discharge, and/or marsh pore-water exchange with tides. In addition, several freshwater creeks (e.g. Spring Branch, Green Valley, Ledgewood, Denverton) drain into Suisun Marsh.

Suisun Marsh consists of large, flow-through sloughs that connect the estuary to networks of small, deadend sloughs that transect tidal marsh plains and managed tidal ponds. In these large and small sloughs, bottom substrates comprise either compacted or loose sediments, respectively (Baumsteiger et al. 2017). Sloughs are either flanked by gradually sloping berms formed by tides or by riprap/peat levees constructed to prevent unmanaged flooding and are lined with emergent vegetation such as tules (Schoenoplectus spp.), cattails (Typha spp.), and common reed Phragmites

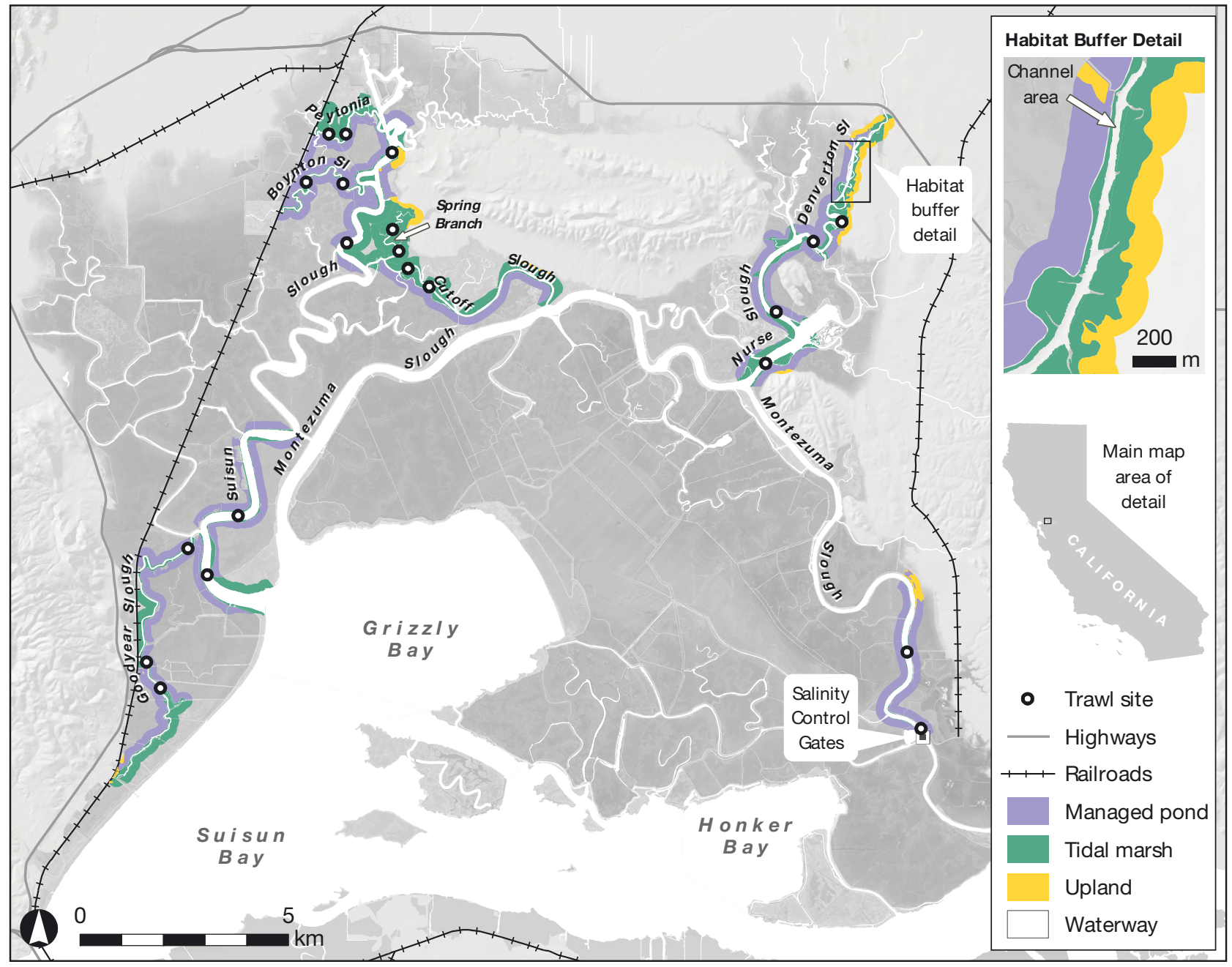

Fig. 1. Long-term trawl survey sites and adjacent land cover buffers calculated in Suisun Marsh, a large brackish wetland complex in the San Francisco Estuary, California, USA. Data: CalAtlas (2012), Department of Water Resources Atlas (2018, http://atlas-dwr.opendata.arcgis.com), Gesch et al. (2002), San Francisco Estuary Institute (2012), US Geological Survey (2004) 
australis. Submersed macrophytes (e.g. Stuckenia spp.) are patchily distributed along some shallow depositional banks, but they are not abundant, likely due to high turbidity limiting light (Moyle et al. 2014). A tidal marsh reserve (Rush Ranch National Estuarine Research Reserve) with reticulate slough networks and natural marsh-plain flooding of pools and ponds represents the largest remaining undiked tidal marsh in Suisun Marsh $\left(4.24 \mathrm{~km}^{2}{ }_{i}<1 \%\right.$ of total Suisun Marsh area; Whitcraft et al. 2011, Enright et al. 2013) .

The Mediterranean climate drives annual and seasonal variability in freshwater flows from 2 major rivers, the Sacramento and San Joaquin, which drain California's Central Valley, flowing through the Delta and then into Suisun Marsh and San Pablo Bay. River regulation from dams has dampened seasonal variability, especially in the wet season from winter and spring. However, precipitation patterns, ranging from prolonged droughts to extreme wet years, remain the primary driver of estuary-wide hydrology, and Delta flows have substantial impacts on water quality in Suisun Marsh. Semidiurnal tides transport salt water from the Pacific Ocean up the axis of the estuary twice a day. From autumn to spring during dry periods, a large salinity control structure in eastern Montezuma Slough restricts flow of saltier waters from the estuary on flood tides and subsequently traps inflows from the fresher Delta on ebb tides. This results in a net movement of lower-salinity water from east to west through Suisun Marsh. The gates are operated by law to create favorable conditions for freshwater vascular plants, widely viewed as the preferred food of wild ducks and geese, in managed tidal ponds (Moyle et al. 2014).

Managed tidal ponds are typically located between sloughs or at their ends. During the waterfowl-hunting season (October to February), tidal waters are slowly circulated through gated culverts and water levels are maintained with flashboards. In winter and spring, punctuated flood-and-drain events occur in the ponds to remove salts from pond soils to encourage desired plant growth. Over the summer season, dry ponds subside as peat soils oxidize (Moyle et al. 2014). This water management schedule modestly overlaps with the young-of-the-year (YOY) fish recruitment window (i.e. spring to autumn).

\subsection{Surveys}

The UC Davis Suisun Marsh Fish Study is a fishmonitoring program that was started to document fish population trends in tidal sloughs (Meng et al. 1994) and is commonly used to examine long-term change in the ecosystem relative to other changes in the San Francisco Estuary. We analyzed data from monthly otter-trawl surveys conducted from 1995 to 2017 in 9 sloughs, which is the program's longest comprehensive time series across Suisun Marsh. Otter-trawl surveys were conducted during daylight and across all tides permitting boat access. Nets were towed along the channel bottom for 5 min in small sloughs or 10 min in large sloughs, during which bottom depths (m) were averaged among 1 or 2 min intervals, respectively, from a transom-mounted transducer. Fish were identified to species, measured in standard length $(\mathrm{SL}, \mathrm{mm})$, and released. Temperature $\left({ }^{\circ} \mathrm{C}\right)$, specific conductivity $(\mu \mathrm{S})$, salinity $(\mathrm{ppt})$, dissolved oxygen $\left(\mu \mathrm{g} \mathrm{l}^{-1}\right)$, and Secchi depth $(\mathrm{cm})$ were recorded at each trawl site with a Yellow Springs Instrument 85 or Pro 2030 device and a $20 \mathrm{~cm}$ white disk.

Focal species selected for this study were 4 common fishes that have historically dominated YOY catch in otter-trawl surveys, and which represent diverse life-history strategies (Table 1). The Sacramento splittail Pogonichthys macrolepidotus is a large-bodied, benthic-oriented minnow. Sexually

Table 1. Focal species, including species code, common name, binomial, life-history strategy, salinity range, and spawning habitat type (Moyle 2002). All species are native to the San Francisco Estuary except for the naturalized striped bass

\begin{tabular}{|lccccc|}
\hline Code & Common name & Binomial & Life history & Salinity range & Spawning habitat \\
\hline SPT & Sacramento & Pogonichthys & Transient & Euryhaline & Riverine \\
splittail & macrolepidotus & (semi-anadromous) & Tloodplain \\
Striped bass & Morone saxatilis & Transient & Euryhaline & Riverine \\
TUP & Tule perch & Hysterocarpus traski & Resident & Freshwater- & Estuarine/ \\
& & & mesohaline & riverine \\
STAFLO & Starry flounder & Platichthys stellatus & Transient (marine) & Euryhaline & Coastal/ \\
& & & & & estuarine \\
\end{tabular}


mature adults migrate to fresh water to spawn on floodplains in winter and spring, after which YOY migrate to the low-salinity zone to rear in tidal marshes, including those of Suisun Marsh (Moyle et al. 2004). The striped bass Morone saxatilis is a large, predatory, anadromous species that was introduced to California in 1879 (Scofield 1931) and also rears in nearshore habitats in the low-salinity zone (Sommer et al. 2011). The tule perch Hysterocarpus traski is a native live-bearing resident associated with vegetation in freshwater and brackish environments (Baltz \& Moyle 1982). The starry flounder Platichthys stellatus is a native marine transient species that makes seasonal migrations into shallow coastal or estuarine habitats (Kimmerer et al. 2009). Collectively, these species represented $55 \%$ of the total trawl catch $(\mathrm{n}=$ 140 092).

\subsection{Analyses}

\subsubsection{Stationary habitat features along the estuarine-terrestrial gradient}

We calculated stationary habitat variables by using heads-up digitizing and aerial photographs from 2015, in which polygons were drawn to represent channel edges and delineate wetland habitats at 1:3000 scale or better. First, slough polygons surrounding otter-trawl transects were identified and channel areas were calculated. Second, we identified land cover types (i.e. emergent marsh, managed tidal pond, upland) and calculated their respective areas within 10 to $200 \mathrm{~m}$ buffers directly surrounding channel polygons. The $200 \mathrm{~m}$ buffers were selected for the analysis to capture the greatest diversity of land cover types and zone of terrestrial influence around sampled sloughs. Buffers $>200 \mathrm{~m}$ were deemed too large due to overlap among sites. The marsh to open water (OW) ratio was calculated as the emergent marsh polygon area divided by the channel polygon area $\left(\mathrm{m}^{2}\right.$; Shafer \& Streever 2000). The metric was intended to characterize the extent of biogenic habitat (i.e. vegetated structure that governs the exchange of nutrients and organisms across the landwater interface) that may influence nursery function in tidal marshes (Boström et al. 2011, Litvin et al. 2018). Due to the importance of marsh to OW ratios to fish in previous studies (Weinstein et al. 2001, Teal \& Weinstein 2002, Litvin et al. 2018, Hammock et al. 2019), we replicated the approach for the other hydrologically connected land cover types (i.e. managed tidal pond and upland) to characterize estuarine-terrestrial gradients among sampled sloughs; the resulting variables are hereafter referred to as 'Marsh:OW,' 'Pond:OW,' and 'Upland:OW.' The sums of these metrics are 'Wetland:OW,' which includes tidal marsh and managed tidal ponds, and 'Land: OW,' which includes all 3 land cover types (i.e. tidal marsh, managed tidal pond, upland). Recorded depths from trawl surveys were used to calculate means and standard deviations of channel depths. Lastly, sinuosity $(S)$, defined as the ratio of meander intrinsic length $(L s)$ along the channel axis and its Cartesian length $(L x)$ (Marani et al. 2006), was estimated in each slough as a measure of channel complexity. The resulting stationary habitat variables (Table 2) were then plotted to examine variances and correlations. Regions were delineated as 'east' and 'west,' and Suisun Slough was separated into upper and lower sections based on Matern et al. (2002), which yielded a total of 10 study sloughs.

Table 2. Stationary habitat features of sampled sloughs. Ratios of land cover area to open water (OW) area were calculated using $200 \mathrm{~m}$ buffers surrounding slough polygons. Wetland:OW is the sum of marsh and pond areas divided by open water area. Land:OW is the sum of marsh, pond, and upland areas divided by open water area. FW: freshwater; WWTP: waste-water treatment plant. Depths were measured in meters

\begin{tabular}{|c|c|c|c|c|c|c|c|c|c|c|}
\hline Slough & Region & $\begin{array}{l}\text { Marsh: } \\
\text { OW }\end{array}$ & $\begin{array}{l}\text { Pond: } \\
\text { OW }\end{array}$ & $\begin{array}{l}\text { Upland: } \\
\text { OW }\end{array}$ & $\begin{array}{l}\text { Land: } \\
\text { OW }\end{array}$ & $\begin{array}{l}\text { Wetland: } \\
\text { OW }\end{array}$ & $\begin{array}{c}\text { Sinuosity } \\
(S)\end{array}$ & $\begin{array}{l}\text { Depth mean } \\
\text { (SD) }\end{array}$ & $\begin{array}{c}\text { Local FW } \\
\text { creek/input }\end{array}$ & $\begin{array}{l}\text { Channel } \\
\text { type }\end{array}$ \\
\hline Boynton & West & 2.20 & 7.70 & 0.00 & 9.90 & 9.90 & 1.97 & $3.1(1.0)$ & WWTP & Dead-end \\
\hline Cutoff & West & 5.55 & 3.91 & 0.13 & 9.59 & 9.46 & 1.47 & $2.3(0.6)$ & Overland & Flow-through \\
\hline Denverton & East & 3.27 & 3.07 & 2.20 & 8.54 & 6.34 & 1.62 & $3.1(1.1)$ & Seasonal & Dead-end \\
\hline Goodyear & West & 7.04 & 9.18 & 0.17 & 16.38 & 16.21 & 1.46 & $2.3(1.0)$ & Overland & Dead-end \\
\hline Montezuma & East & 0.26 & 3.18 & 0.26 & 3.71 & 3.45 & 1.23 & $6.2(2.3)$ & Overland & Flow-through \\
\hline Nurse & East & 1.45 & 1.95 & 0.04 & 3.45 & 3.41 & 1.42 & $5.3(2.4)$ & Overland & Flow-through \\
\hline Peytonia & West & 8.00 & 5.08 & 0.00 & 13.08 & 13.08 & 1.92 & $2.8(0.9)$ & Perennial & Dead-end \\
\hline Spring Branch & West & 14.25 & 0.00 & 2.24 & 16.49 & 14.25 & 2.00 & $1.7(0.6)$ & Seasonal & Dead-end \\
\hline Suisun Lower & West & 0.68 & 1.26 & 0.00 & 1.94 & 1.94 & 1.87 & $4.0(1.8)$ & Overland & Flow-through \\
\hline Suisun Upper & West & 0.90 & 1.18 & 0.15 & 2.22 & 2.08 & 1.40 & $5.8(2.1)$ & Overland & Flow-through \\
\hline
\end{tabular}




\subsubsection{Annual and seasonal abundance, distribution, and apparent growth}

To evaluate spatial and temporal shifts among fish species and life stages, we used estimated age classes established in a previous analysis of lengthfrequency histograms (Manfree 2014). Three distinct groups (likely YOY, age-1, and age-2+) were identified for Sacramento splittail, striped bass, and starry flounder. Two distinct groups (likely YOY and age$1+)$ were identified for tule perch. Due to very small catches of age-2+ starry flounder, we pooled catches for age- 1 and age-2+ to create an age-1+ grouping.

To understand annual trends in the abundance and age-class structure of each species across the $22 \mathrm{yr}$ study duration, we used generalized additive mixed models (GAMMs). GAMMs are flexible hierarchical non-linear regression functions that allow smooth relationships between predictor and response variables to vary between groups and are commonly used to model time-series data (Pedersen et al. 2019). Specifically, we modeled annual species catches with year as a main effect with smoothness that was allowed to vary as a function of estimated age class. Trawl site (i.e. repeat visits to each sampling location) was included as a random-effect grouping variable. The year parameter included a thin plate regression spline (TPRS), a general-purpose spline that smooths the relationship between predictor and response variables (Wood 2003). The number of trawl minutes was log-transformed and included as an offset variable to adjust for differences in sampling effort (i.e. 5 or 10 min trawls). We used a Poisson distribution to adjust for skew towards smaller catches observed in the raw data and specified weakly informative priors with a normal distribution for the mean and a halfCauchy distribution for the variance (McElreath 2018).

Next we examined seasonal dynamics of YOY fish abundance and apparent growth by slough. We modeled YOY fish abundance using a TPRS smoother as described above; in this version, we specified month as a main effect with smoothness that was allowed to vary as a function of slough. Random-effect grouping variables included year, trawl site, and trawl minutes adjusted for sampling effort. A zero-inflated Poisson distribution adjusted the models for excess zeros present in the monthly dataset (i.e. May to November, the YOY recruitment window).

To evaluate apparent growth through time, defined as the average change in the population's size structure (i.e. measured SL, $\mathrm{mm}$ ) across sampling months, we specified month as a main effect that was allowed to vary as a function of slough and the random-effect grouping variables year and trawl site. We used a Gaussian distribution and specified weakly informative Student's $t$-distribution for normally distributed data. We fit all models using the 'No-U-Turn Sampler' (NUTS) extension of Hamiltonian Monte Carlo (Hoffman \& Gelman 2014) with the packages 'brms' (Bürkner 2017, 2018) and 'RStan' (Stan Development Team 2018). We then performed model checking procedures with 'bayesplot' (Gabry \& Mahr 2019) in Program R v3.5.0 (R Core Team 2018).

\subsubsection{Species-habitat relationships}

We evaluated physical habitat effects on species and age-class distributions via non-metric multidimensional scaling (NMDS) using the package 'vegan' v2.4-6 (Oksanen et al. 2018) in Program R v3.5.0 (R Core Team 2018). First, we constructed a Bray-Curtis dissimilarity matrix describing annual CPUE for each species, age class, and slough combination. Next, we fit stationary habitat features (Table 2) and water-quality variables to the ordination. Missing values for monthly water-quality variables were imputed using predictive mean matching in the package 'mice' (Buuren \& Groothuis-Oudshoorn 2011), and then mean annual specific conductivity, temperature, and Secchi depth were calculated for each slough. Species, age classes, and sloughs were plotted along with fitted environmental variables. In addition, we termed sloughs that had ratios of land to open water $>4$ within their $200 \mathrm{~m}$ polygon buffers as 'land-dominated' and the others as 'open-water-dominated,' then projected their mean NMDS values as ellipses on the ordination biplot to look for broader, seascape-scale differences in species and age-class distributions across the estuarine-terrestrial gradient.

\subsubsection{Land-water interactions}

We also tested for effects of land-water interactions on nursery function by modeling YOY and age-1+ abundances using generalized linear mixed models (GLMMs; McElreath 2018). We used season, year, and trawl site as random-effect grouping variables for each species and age-class combination (Table 3). The number of trawl minutes was logtransformed and included as an offset variable to adjust for differences in sampling effort. Net Delta outflow, an estimate of daily average outflow from 
Table 3. Definitions of predictor variables used in generalized linear mixed models

\begin{tabular}{|llc|}
\hline Variable & Definition & Type \\
\hline Effort & Number of minutes trawled & Numeric \\
Site & Trawl survey location & Categorical \\
Year (Yr) & Year that trawl survey occurred & Categorical \\
Season (Sn) & Season that trawl survey occurred \\
Depth & Average water depth of trawl site & Numeric \\
Land:OW (LOW) & Ratio of land (marsh, pond, upland) area to open water area & Numeric \\
Wetland:OW (WOW) & Ratio of wetland (marsh, pond) area to open water area & Numeric \\
Marsh:OW (MOW) & Ratio of marsh area to open water area & Numeric \\
Pond:OW (POW) & Ratio of pond area to open water area & Numeric \\
Upland:OW (UOW) & Ratio of upland area to open water area & Numeric \\
Sinuosity $(S)$ & Ratio of meander intrinsic length along the channel axis and its Cartesian length & Numeric \\
Outflow & Net delta outflow & Numeric \\
\hline
\end{tabular}

the upstream Delta (https://data.cnra.ca.gov/dataset/dayflow), was averaged by season and year and $z$-score transformed (mean $=0, \mathrm{SD}=1$ ) to attribute seasonal and annual differences to the season and year categorical variables (Zuur et al. 2009). All stationary habitat variables were mean centered (mean $=0$; see Table 3 ). Next, we examined the standardized variables for multicollinearity by calculating variance inflation factors in the package 'car' (Fox \& Weisberg 2018) and selected combinations of variables that yielded values below 2 (Zuur et al. 2009). Because we anticipated that freshwater flows would strongly influence the abundance of focal species (Meng \& Matern 2001, Matern et al. 2002), we chose to examine both additive and 2way interaction effects among Delta outflow and each stationary habitat variable to see which combinations improved model predictions. To do so, we constructed varying-intercept GLMMs with a Poisson distribution and specified weakly informative priors with a normal distribution for the mean and a half-Cauchy distribution for the variance, respectively (mean prior: 0,10; variance prior: 0,1; McElreath 2018). We fit all models and conducted posterior predictive checks using the same Program $\mathrm{R}$ packages as described in the GAMM analysis. Then we compared model results using leave-oneout cross-validation with the package 'loo' (Vehtari et al. 2018). The leave-one-out cross-validation information criterion (looic) was calculated by taking averages of log-likelihood over the posterior distribution. Model (Akaike) weights for each model were interpreted as 'an estimate of the probability that the model will make the best predictions on new data, conditional on the set of models considered' (McElreath 2018, p. 199).

\section{RESULTS}

\subsection{Overall patterns in Suisun Marsh}

Survey data showed that focal species exhibited resident or transient life-history strategies (Table 1), corroborating literature within the San Francisco Estuary and other estuaries where the species occur (Moyle 2002). Tule perch were present in Suisun Marsh year-round and thus were the only true resident in the present study. Splittail were also present throughout the year, but we did not consider them strictly resident, because most sexually mature adults make spawning migrations upriver in winter months (Moyle et al. 2004) and most YOY in Suisun Marsh come from floodplains (e.g. Yolo Bypass; Sommer et al. 1997, Feyrer et al. 2010). Striped bass and starry flounder were found in Suisun Marsh primarily as YOY in summer and autumn, after which recruits likely dispersed throughout the estuary. Large fish of both species were likely inadequately captured by otter trawl because they are better able to avoid or escape the net, so they may have been more abundant than the data indicated. However, large striped bass are caught year-round by anglers in Suisun Marsh (T. A. O'Rear unpubl. data).

GAMM predictions indicated that species exhibited wide interannual variability in abundance. Across the entire dataset, striped bass yielded the highest predicted CPUE, followed by Sacramento splittail and tule perch; starry flounder were periodically present in Suisun Marsh but in relatively low numbers (Fig. 2). YOY were numerically dominant compared to older age classes for striped bass and starry flounder but not for splittail or tule perch, which also had high numbers of older age classes. 

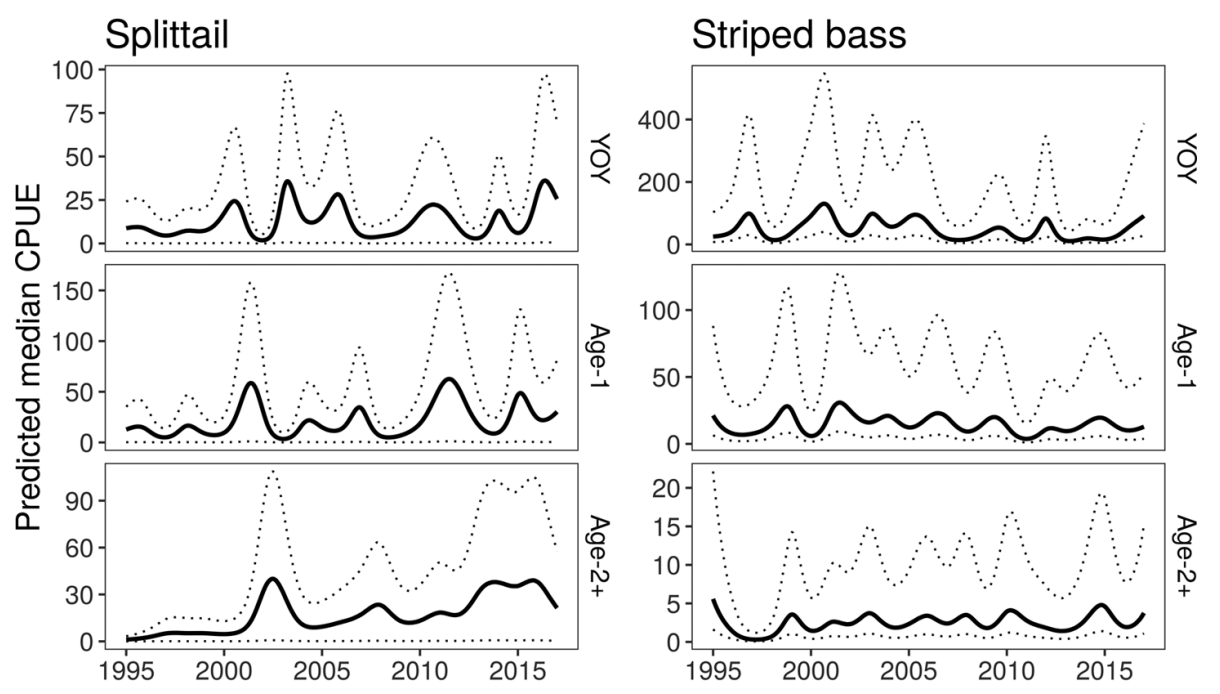

\section{Tule perch}

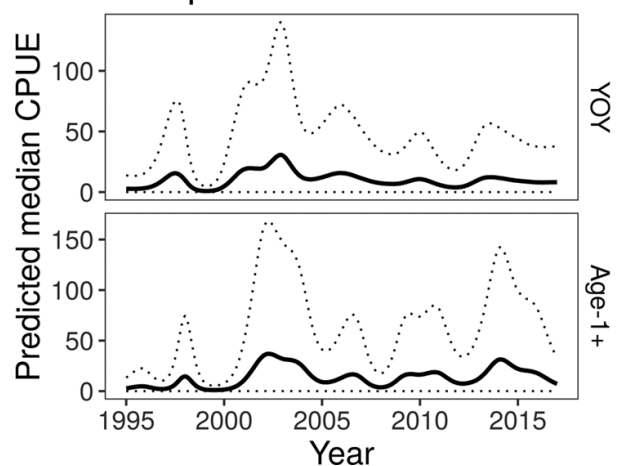

Starry flounder

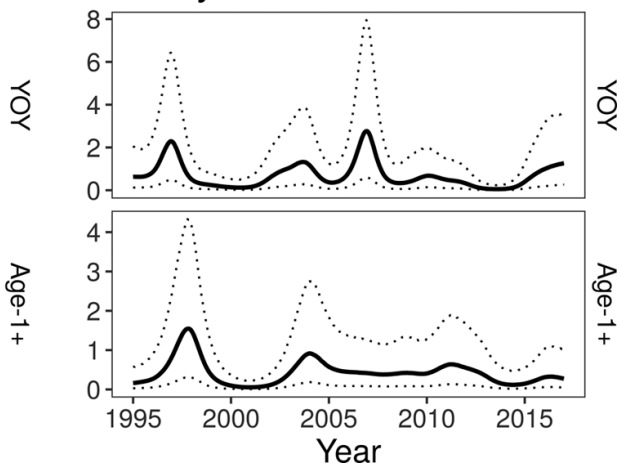

Fig. 2. Annual catch-per-uniteffort (CPUE) trends of focal species and age classes monitored in Suisun Marsh. Black lines indicate predicted median estimates from generalized additive mixed models; dotted lines indicate 95\% credible intervals around the median

Timing of recruitment into Suisun Marsh from downstream saltwater habitats (starry flounder), upstream freshwater habitats (Sacramento splittail and striped bass), or local reproduction within Suisun Marsh itself (tule perch) generally peaked in summer (see Fig. S1 in the Supplement at www.int-res.com/articles/suppl/ m637p141_supp.pdf). Across Suisun Marsh, predicted CPUE of YOY striped bass peaked earlier in the season (May to June). Conversely, YOY starry flounder peaked in July and August, and both YOY tule perch and splittail peaked in August. Predicted CPUE of all species subsequently declined as months progressed.

\subsection{Fine-scale spatial and temporal patterns of YOY fish}

According to the YOY GAMM results, fine-scale temporal and spatial variation occurred among species with respect to abundance; however, there was little evidence for differences in apparent growth rate except for tule perch in summer (Fig. 3). For splittail, the predicted YOY CPUE was greatest overall in western dead-end sloughs (Spring Branch and Goodyear), where it peaked earlier in summer (June and July), whereas eastern sloughs (Nurse and Denverton) became relatively more important from late summer to autumn. Predicted body size and apparent growth rate followed similar trajectories over time but showed variability among sloughs in June and July, during the peak recruitment period, when young splittail were moving into Suisun Marsh from upstream floodplain habitats (median SL: 32$44 \mathrm{~mm}$ ). Notably, during this period, sloughs with the highest predicted abundance only had average predicted apparent growth rates (change in median predicted SL: $\sim 14 \mathrm{~mm} \mathrm{mo}^{-1}$ ).

For striped bass models, predicted YOY CPUE was disproportionately greater in the dead-end slough Spring Branch from May to June. The initial predicted body sizes in May and June were 6 and $18 \mathrm{~mm}$, respectively, reflecting the movement and settlement of larval and post-larval fish into Suisun Marsh from late 
A Monthly CPUE Splittail YOY
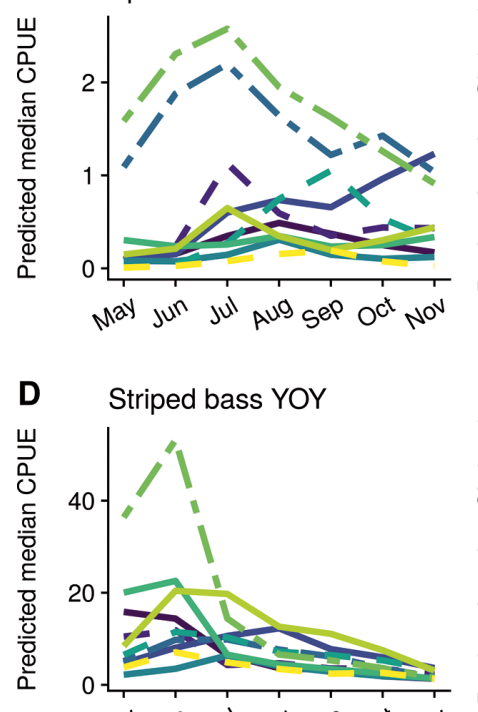

may jun jul and geb ock noN

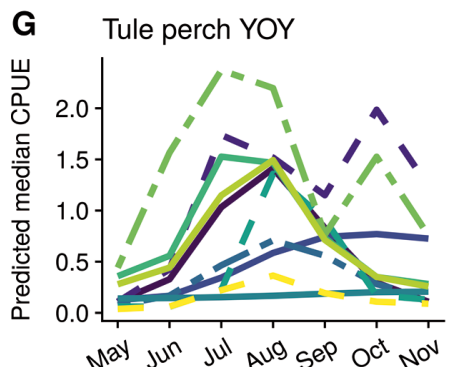

may jun jul aud geb oct nov

J Starry flounder YOY

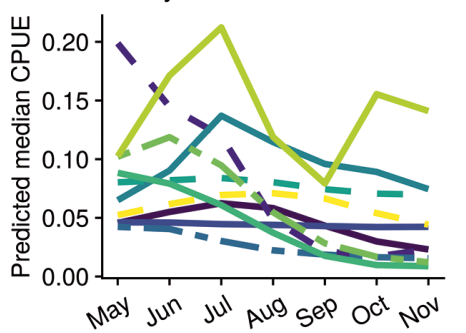

Month
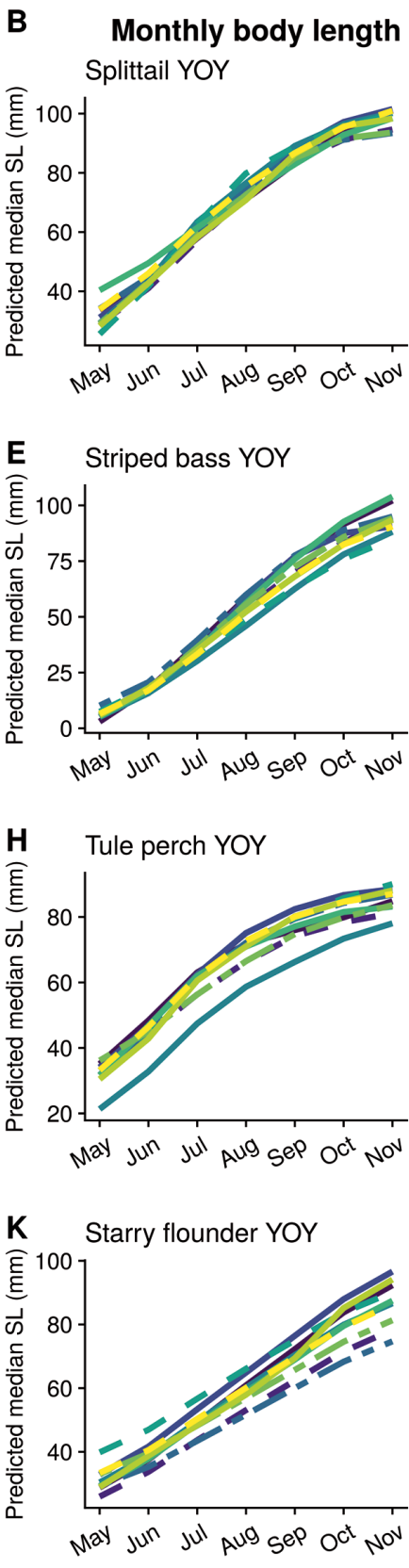

Month
$\mathbf{F}$
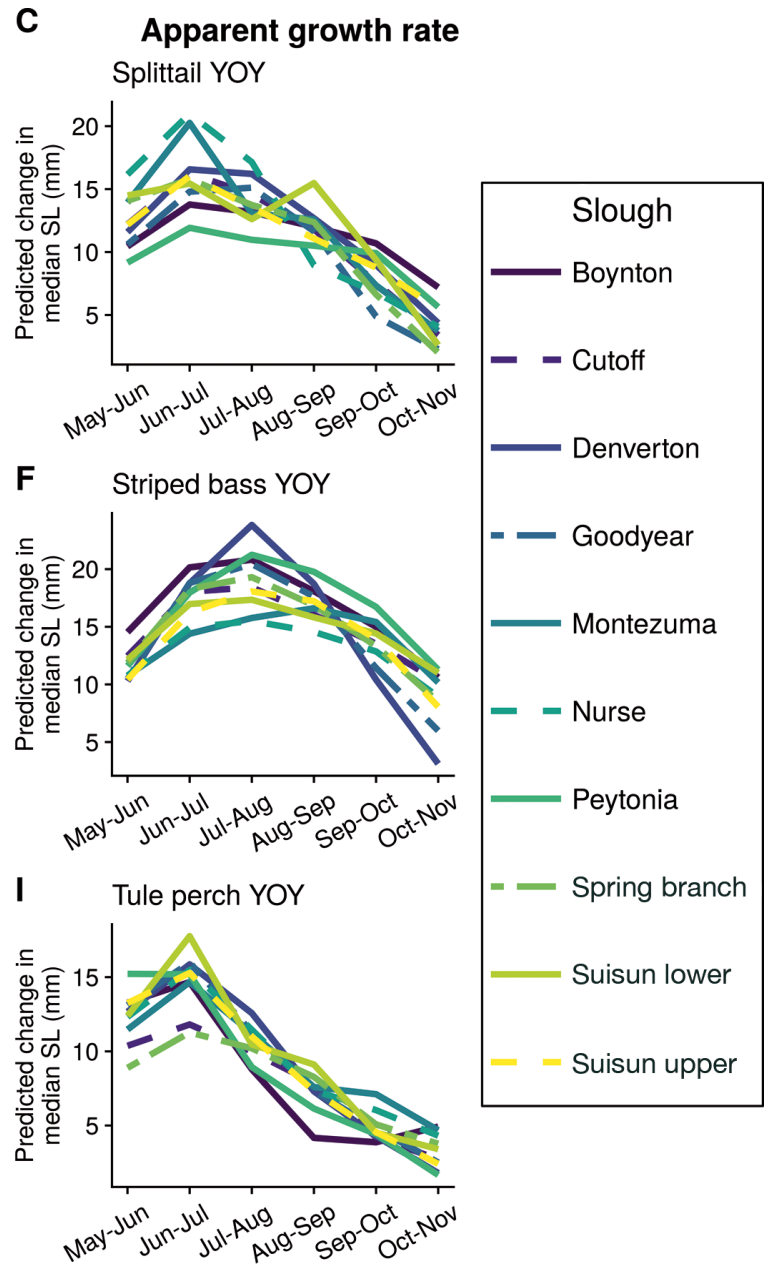

L Starry flounder YOY

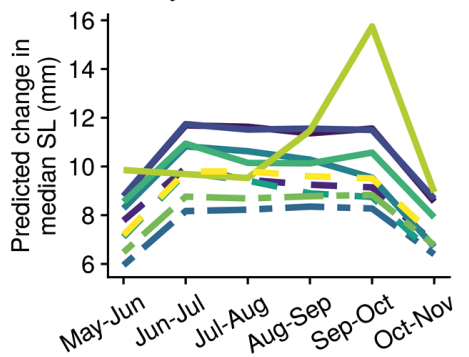

Period

Fig. 3. Seasonal dynamics for predicted young-of-the-year (YOY) catch-per-unit-effort (CPUE), body length (standard length, $\mathrm{SL})$, and growth rates in Suisun Marsh. Lines indicate predicted median estimates from generalized additive mixed models and colors and line types represent sloughs. Panels represent model predictions for focal species: (A-C) Sacramento splittail,

(D-F) striped bass, (G-I) tule perch, and (J-L) starry flounder

spring to early summer (Fig. 3). The predicted apparent growth rates were also similar among sloughs during this time. However, other sloughs yielded higher predicted CPUE across seasons (Denverton and lower Suisun sloughs; Figs. S2 \& S3).

Model predictions for YOY tule perch indicated that various sloughs yielded higher CPUE on a seasonal basis; for example, the dead-end slough Spring Branch yielded disproportionately greater predicted CPUE in summer (June to August), which coincided with the smallest predicted apparent growth rates among sloughs; similarly, Cutoff Slough, a flow-through slough draining Spring Branch, yielded the greatest predicted CPUE in 
autumn and also had relatively low predicted apparent growth rates (Fig. 3). Eastern dead-end sloughs (e.g. Denverton) also had higher predicted CPUE in autumn compared to spring and summer. Overall, predicted CPUE was relatively high in other sloughs throughout Suisun Marsh (e.g. Nurse, lower Suisun, Boynton, and Peytonia; Fig. S2). Predicted body sizes of YOY tule perch, which are released as live young by pregnant females, ranged from a median estimate of 32 to $44 \mathrm{~mm}$ in May and June, respectively.

While total sample sizes were relatively low for starry flounder, models clearly indicated that large flow-through sloughs closest to the open estuary (Montezuma and lower Suisun Sloughs) yielded the highest predicted YOY CPUE across the study period. However, Cutoff Slough, a flow-through slough draining Spring Branch, yielded higher CPUE in early summer months, which coincided with the smallest predicted body sizes (Fig. 3). Overall, predicted median body sizes ranged from 31 to $86 \mathrm{~mm}$ from May to November, respectively, and predicted apparent growth rates peaked across all sites in midsummer months, except for lower Suisun Slough, where they peaked in autumn.

\subsection{Stationary habitat features}

Each sampled slough had a different combination of values for the land to OW variables (Table 2). Ratio estimates yielded Marsh:OW > 0 for all sloughs, Pond:OW $>0$ for 9 of 10 sloughs, and Upland:OW > 0 for 6 of 10 sloughs, reflecting geographic, geomorphic, and management differences across Suisun Marsh. The western dead-end slough, Spring Branch, which is located in the large tidal marsh reserve, represented the highest Marsh:OW and Upland:OW ratios and sinuosity, and the lowest Pond:OW ratio and channel depth. Despite differences in land cover type and areas, several sloughs had similarities between the more general Land:OW and Wetland:OW values. For example, the western dead-end sloughs Spring Branch and Goodyear had different proportions of marsh and pond areas, but when these values were pooled, both sloughs yielded the highest observed Land:OW and Wetland:OW values (>14). In contrast, the largest and deepest flow-through sloughs sampled in the study (lower Suisun, upper Suisun, Montezuma, and Nurse) yielded the lowest Land:OW and Wetland: OW values $(<4)$ and were categorized as 'openwater-dominated.'

\subsection{Freshwater flows and water-quality conditions}

Delta outflow data indicated that over the $22 \mathrm{yr}$ study duration, 8 years were designated as 'wet' and 8 were designated as 'dry' or 'critically dry,' reflecting California's variable hydrologic conditions, which feature extreme wet years and multi-year droughts (Figs. S4-S7). For example, the time series started out with consecutive wet years (water years 1995-1998) and ended with a 4 yr drought (water years 2012-2015) and the highest water-year on record (2017). Within Suisun Marsh, water quality was variable on regional and local scales. Consistent with the literature, there was a regional salinity gradient from east to west, illustrating a transition from fresher to saltier conditions as a function of the distance from the Sacramento-San Joaquin Delta to the east and San Francisco Bay to the west. For example, Montezuma, Nurse, and Denverton sloughs in eastern Suisun Marsh were more freshwater-influenced, averaging 3 ppt and ranging from 0-12.4 ppt. In contrast, Suisun and Goodyear sloughs in southwest Suisun Marsh were consistently the saltiest, averaging 6 ppt and ranging from 0-16.8 ppt.

Temperature ranges also varied across sloughs and were related to channel depth. For example, Montezuma, a deep flow-through slough that connects Suisun Marsh to the main axis of the estuary, had the lowest recorded summer temperature maximum $\left(23.9^{\circ} \mathrm{C}\right)$, whereas the shallowest dead-end slough (Spring Branch) had the highest recorded summer temperature maximum $\left(32.1^{\circ} \mathrm{C}\right)$ throughout the time series. Water clarity, as measured by Secchi depth, was generally higher and more variable in openwater-dominated sloughs. Seasonal and annual differences drove these patterns, whereby autumn months with low flows were on average clearer, especially in larger sloughs.

\subsection{Species-habitat relationships over ontogeny}

The ordination indicated that the focal species were distributed across the estuarine-terrestrial gradient, whereby YOY striped bass, splittail, and tule perch were more associated with shallower sloughs with higher Land:OW ratios (Fig. 4). Results from a 2-dimensional NMDS analysis yielded a stress level $<0.2$ (stress $=0.14$ ) and fitted environmental variables yielded significant results for depth, Marsh: OW, Upland:OW, and Land:OW ratios, and salinity at a $<0.05$ level, and Pond:OW and temperature at a $<0.1$ level. To visualize relationships among species 


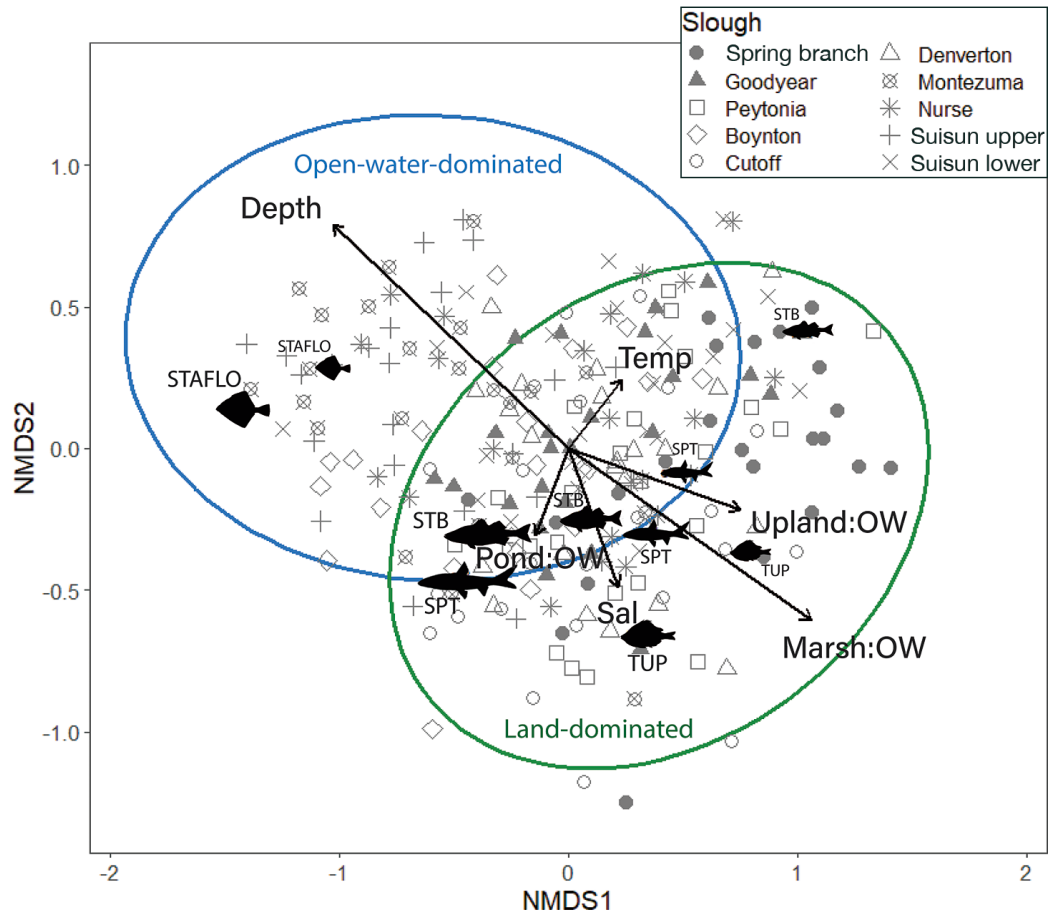

Fig. 4. Non-metric multidimensional scaling (NMDS) biplot results. Points represent sampling events pooled by year and slough. Text and symbols represent species codes (see Table 1) and age classes are represented by small (YOY), medium (age-1), or large (age-1+/ age-2+) symbols. Ellipses represent mean NMDS values grouped by open-water (OW)-dominated habitat (blue) or land-dominated habitat (green). Arrows are fitted environmental variables

with respect to the estuarine-terrestrial gradient, Land:OW was depicted as a categorical factor in ordination space (i.e. 'land-dominated' = Land:OW $>4$ and 'open-water-dominated' = Land:OW <4), where mean NMDS values for each category were projected as ellipses.

Species and age classes varied in their use of openwater-dominated and land-dominated sloughs. YOY striped bass were positively related to shallow, warm, land-dominated sloughs and negatively related to managed tidal ponds; age- 1 striped bass were closer to the center of the ordination, whereas age-2+ were more associated with ponds and cooler temperatures. Sacramento splittail had a similar distribution as striped bass, but the strengths of the relationships were weaker. YOY tule perch were associated with shallower depths, marshes, and uplands, and age-1+ tule perch had similar associations except that they were also associated with saltier water and ponds. While YOY striped bass, YOY tule perch, and age-1+ tule perch were strongly associated with land-dominated sloughs, the NMDS ellipses indicated that splittail and older age classes of striped bass were associated with both land- and open-water-dominated sloughs. Conversely, YOY and age-1+ starry flounder were strongly associated with deeper, open-water-dominated sloughs, and drove major observed differences in the focal community.

\subsection{Land-water interactions and nursery function}

Modeled relationships of fish abundance as a function of stationary habitat features and flow conditions varied by species and estimated age class. In general, models tended to slightly under-predict zeros and over-predict intermediate fish counts (Figs. S8 \& S9). The random-effect grouping variables year, trawl site, and season were important in all models. In particular, the year variable had a strong but highly variable effect for the focal transient species, likely due to interannual variability in reproduction success and/or prevailing environmental conditions affecting transient species in the estuary, river, or ocean. Season was similarly strong, indicating that summer yielded strong associations with YOY abundances. Model coefficients for the trawl site term were highly variable and indicated relatively strong effects for all estimated age classes of tule perch and older splittail (Table 4, Fig. 5).

Overall, the sizes of interaction effects were smaller than random effects, which captured the high variability in temporal and spatial trends in the dataset. Outflow was an important predictor for all species and, as hypothesized, its effect was dependent on the effect of stationary habitat variables as indicated by smaller 'loo' values for models specifying 2-way interaction effects (Table 4, Fig. 5). Interestingly, YOY splittail, striped bass, and tule perch abundances were best predicted by the interaction of freshwater flows and depth, whereby splittail and striped bass were positively related to higher flows and shallower water. Notably, tule perch showed the inverse relationship, whereby they were positively related to lower flows (i.e. drought conditions) and shallower water. Channel depth was correlated with several other metrics, including Marsh:OW and Land:OW ratios and sinuosity, but provided better predictions as indicated by 'looics,' out-of-sample deviances, and model weights (see Table 4 for a summary; Table S1 for full model comparisons). Shared 
Table 4. Summary of top-ranked models for each species (see Table 1) and age class; looic: estimated out-of-sample deviance; ploo: estimated effective number of parameters; SE: standard error of the looic estimate. See Section 2.3.4 for details. Randomeffect grouping variables included season, year, and site (i.e. revisited trawl location in the long-term monitoring study). '+' and ' $x$ ' indicate additive and interaction effects, respectively. Model selections were based on a combination of model weights and prediction performance. See Table S1 in the Supplement for full model comparisons

\begin{tabular}{|c|c|c|c|c|c|c|c|c|}
\hline $\begin{array}{l}\text { Species } \\
\text { code }\end{array}$ & $\begin{array}{l}\text { Age } \\
\text { class }\end{array}$ & $\begin{array}{c}\text { Model } \\
\text { no. }\end{array}$ & Rank & Equation & looic & ploo & $\begin{array}{c}\text { Model } \\
\text { weight }\end{array}$ & SE \\
\hline SPT & YOY & 24 & 1 & Effort + Site + Year + Season + Outflow $\times$ Depth & 7515.4 & 429.6 & 1.00 & 516.19 \\
\hline SPT & Age-1+ & 26 & 1 & Effort + Site + Year + Season + Outflow $\times$ Sinuosity & 14635.3 & 532.4 & 1.00 & 745.92 \\
\hline STB & YOY & 24 & 1 & Effort + Site + Year + Season + Outflow $\times$ Depth & 39388.4 & 1972.5 & 1.00 & 3362.50 \\
\hline STB & Age-1+ & 26 & 1 & Effort + Site + Year + Season + Outflow $\times$ Sinuosity & 17831.0 & 872.9 & 1.00 & 1675.22 \\
\hline TUP & YOY & 24 & 1 & Effort + Site + Year + Season + Outflow $\times$ Depth & 7916.2 & 441.3 & 1.00 & 509.22 \\
\hline TUP & Age-1+ & 22 & 1 & Effort + Site + Year + Season + Outflow $\times$ Upland:OW & 7053.9 & 272.5 & 0.90 & 326.86 \\
\hline STAFLO & YOY & 14 & 1 & Effort + Site + Year + Season + Outflow $\times$ Land:OW & 1912.4 & 102.8 & 0.35 & 128.72 \\
\hline
\end{tabular}

model weights among YOY starry flounder indicated that the 2-way interaction effects of outflow with Land:OW, Marsh:OW, or Wetland:OW ratios all performed similarly, reflecting their relationship to open-water-dominated sloughs. Abundances of larger splittail and striped bass were best predicted by the interaction effect of outflow and sinuosity, whereas larger tule perch were best predicted by the Upland:OW ratio. Larger starry flounder were excluded from the analysis due to unreliable model estimates as indicated by the HMC sampler.

\section{DISCUSSION}

Our study shows that Suisun Marsh is an important seascape nursery for 4 fish species with diverse life histories, a condition that likely relates to other fishes using the area. Our major findings include the following: (1) there are geographic locations that function as YOY hotspots within the seascape nursery; (2) the focal species have diverse life-history adaptations, including seasonal and ontogenetic habitat shifts by transient species; and (3) land-water interactions are likely drivers of nekton diversity and productivity in this nearshore ecosystem. Our study underscores the benefits of long-term datasets in understanding how estuarine habitat mosaics are functionally linked by complex physical and ecological processes. The implication of this study is that cultivating habitat complexity along an estuarineterrestrial gradient, particularly in drowned river valley estuaries, can promote fish species persistence. Specifically, our study highlights process-based nursery functions of slough networks connecting migratory corridors to hotspots, which represent a habitat continuum at the seascape-landscape interface.

\subsection{Fish use of the seascape nursery}

Our observation that YOY splittail, striped bass, and tule perch were consistently abundant in deadend, shallow sloughs across regions of Suisun Marsh (e.g. Spring Branch, Goodyear, Denverton sloughs) suggests that there are 'keystone habitats' within mosaics of connected and interacting habitat patches (Hitchman et al. 2018). Seasonal and ontogenetic habitat shifts by YOY splittail and striped bass seem to drive population connectivity and persistence, and are consistent with previous studies on these species' use of shallow marshes and shorelines in other parts of the estuary (Feyrer et al. 2005, Sommer et al. 2011). Differences in YOY abundance and distribution were clearer than differences in apparent growth. For resident tule perch, lower apparent growth rates in nursery areas early in ontogeny (Cutoff and Spring Branch sloughs from May to July) are suggestive of density-dependent processes, whereby individuals may have spent more time hiding from predators than foraging/growing during this sensitive life stage. Aging and microchemistry studies of calcified structures (e.g. otoliths) would help quantify growth and emigration/immigration rates and should be considered for future studies.

Variation in habitat use among years was also apparent. For example, YOY tule perch were more abundant in interior sloughs during low-flow years, reflecting their adaptations as year-round residents to locally fluctuating conditions (e.g. salinity; Rountree \& Able 2007). Tule perch may also have been responding to increased submersed macrophyte growth during clearer, low-flow years, which may have provided increased localized cover for pregnant females and for their newly released young (Baltz \& Moyle 1982, Moyle 2002, Young et al. 2018). Differ- 

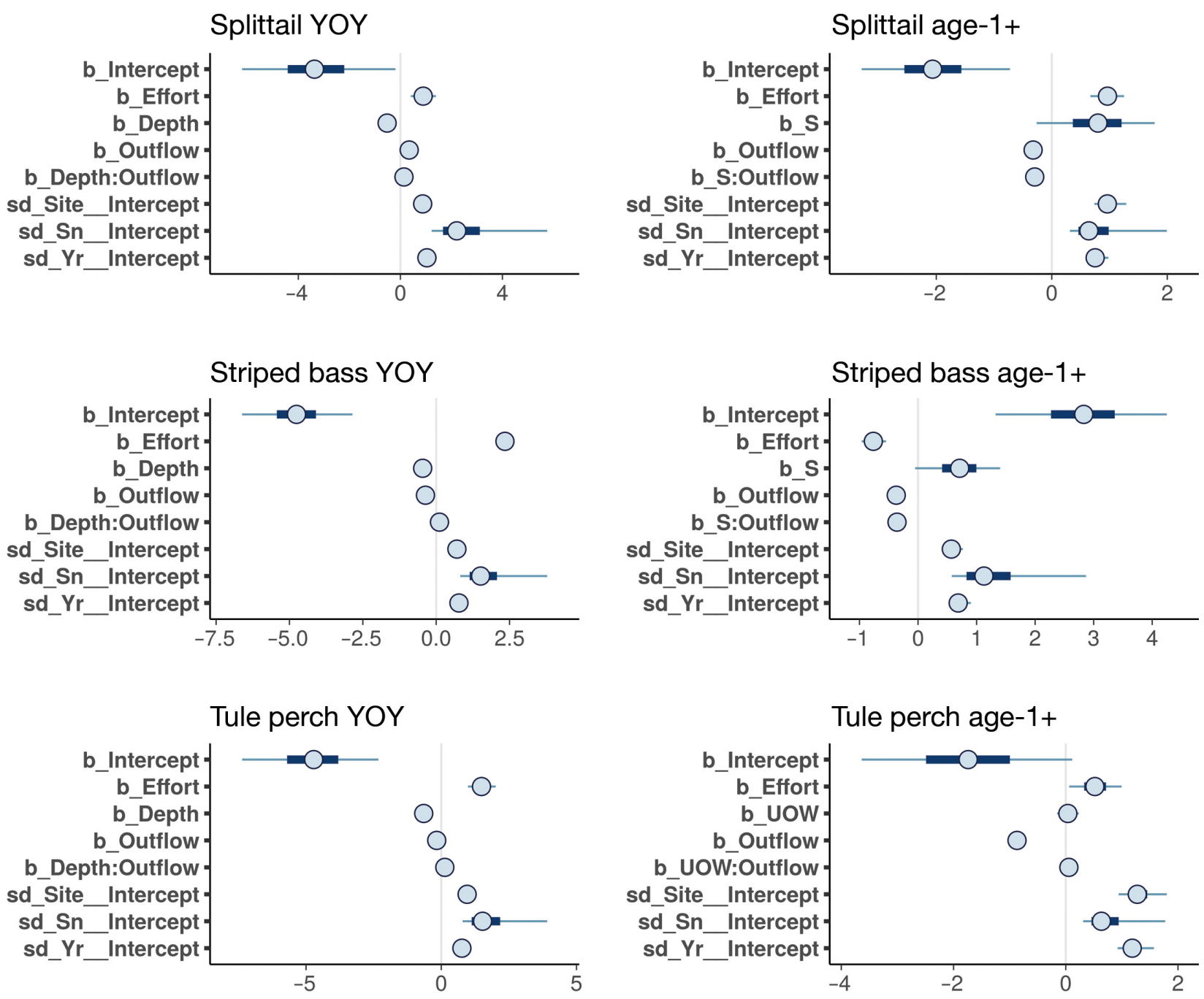

\section{Starry flounder YOY}

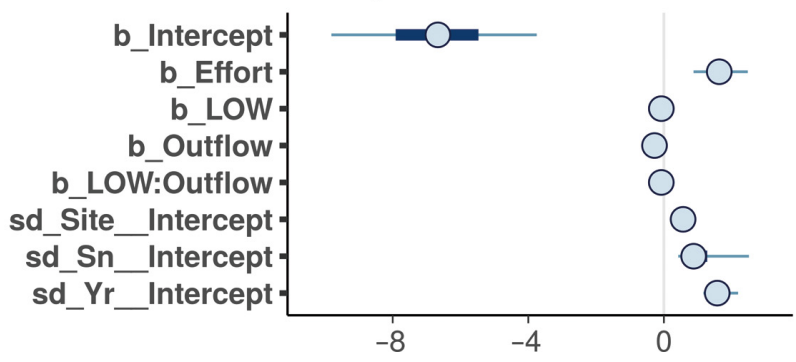

Fig. 5. Model coefficients for top-ranked habitat and flow models. Effect sizes of predictor variables are measured as the strength of the positive $(>0)$ or negative $(<0)$ value on the $x$-axis. Values overlapping 0 represent no discernible effect. Coefficient parameter types are preceded by ' $b$ ' or 'sd' for interaction or random effects, respectively. Predictor variable definitions are given in Table 3

ences in the timing of peak abundance among YOY with different life histories was suggestive of finescale temporal habitat partitioning and may have prevented density-dependent growth where multiple species' hotspots spatially overlapped. On a seascape scale, the redundancy of keystone habitats, each with different physical characteristics, may have played an important role in the persistence of

these species throughout the study duration and across variable hydrologic conditions; if true, redundancy may further explain why Suisun Marsh, a large brackish wetland system with more intact habitat area and complexity compared to other areas in the upper estuary, functioned as a nursery area when conditions were considered unfavorable or unproductive in nearby bays and rivers. 


\subsection{The estuarine-terrestrial gradient in three dimensions}

In Suisun Marsh, the transition from open-waterdominated to land-dominated sloughs propagates in longitudinal, lateral, and vertical dimensions. In the longitudinal dimension, Suisun Marsh features brackish conditions that result from mixing of oceanic waters from San Francisco Bay with fresh water from the Sacramento-San Joaquin Delta in large slough networks formed by fluvial and tidal processes (Moyle et al. 2014). In the lateral dimension, sloughs are connected to a variety of historic and anthropogenic habitats, including shallow vegetated intertidal zones and managed tidal ponds, respectively. In the vertical dimension, fluvial processes connect uplands to tidal marshes, ponds, and sloughs, and, in some cases, form perennial or seasonal freshwater creeks. Based on our observations, we infer that the high degree of complexity within each of these 3 dimensions of Suisun Marsh represents a seascape-landscape interface that, as a whole, supports beneficial conditions for juveniles of a variety of species and life histories.

Channel depth and ratio of marsh to open water were correlated, and highly important, measures of nursery function for native species such as Sacramento splittail and tule perch, and the non-native striped bass. These trends were driven mostly by high YOY catches in Spring Branch, a dead-end slough in the large tidal marsh reserve. Fish may have benefitted from numerous co-occurring physical and ecological processes, which may explain the apparent marsh dependence of small-sized YOY in late spring and summer. Examples of these processes include increased physical access to the marsh plain with increasing length of marsh edge and decreasing stream order (Rozas et al. 1988, Kneib 1997, Visintainer et al. 2006) and tidal exchange of nutrients, sediment, and organisms across the land-water interface (Levin et al. 2001). Shallow depths likely provide small YOY with refuge from large-bodied predatory fishes, which has been documented in other nearshore nurseries (Munsch et al. 2016), and loose sediments likely preclude establishment of invasive clams (e.g. Potamocorbula amurensis; Baumsteiger et al. 2017), which alter pelagic food webs by filtering phytoplankton at high rates. The combination of high densities of zooplankton (Montgomery 2017) and high areal coverage of emergent vegetation in shallow dead-end sloughs likely supports survival and growth of young transient fish by reducing competition for food and space. Also, where fluvial and tidal processes intersect at high marsh elevations, diverse sources of organic matter may contribute to aquatic food webs that include juvenile fish (Odum 1984, Simenstad et al. 2011). Uplands can provide local sources of sediment, nutrients, or fresh water from creeks, seeps, or groundwater, and contribute to both habitat variability and self-sustaining processes such as marsh accretion (Schile et al. 2014, Goals Project 2015). As sea-level rise gradually moves marshes into adjacent uplands (Fagherazzi et al. 2019), sites possessing a marsh-upland transition zone should continue to support both terrestrial and aquatic communities, as well as species persistence and ecological resilience (Weinstein \& Kreeger 2000, Goals Project 2015, Kirwan et al. 2016, Beller et al. 2019).

\subsection{Restoring habitat at the land-water interface}

Re-creating dynamic conditions favorable to small fish in Suisun Marsh now and into the future requires restoration of large swaths of tidal marsh drained by shallow meandering channels that connect to transitional vegetation and grasslands (Fig. 6A). Ideally, such restoration will maintain or even increase juvenile fish abundance and population resilience, and enhance survival during migrations to and from the greater estuary. In scenarios where marsh-upland restoration is not feasible due to dredged channels, leveed banks, lack of sediment, newly introduced noxious species, and/or ongoing land-use practices (e.g. managing ponds for waterfowl), managers may prefer to adopt a reconciliation ecology approach to maintain biodiversity in these human-dominated landscapes (Rosenzweig 2003, Moyle 2014). For example, tidal ponds managed intensively for waterfowl are novel habitats that may function similarly to historic tidal marsh ponds and pools, at least on a seasonal basis, when they are flooded and tidal waters are exchanged with adjacent sloughs. Even if the ponds are not directly occupied, it is possible that fish can benefit from managed tidal pond production when the water is exported to adjacent sloughs (i.e. food subsidies; Weinstein \& Kreeger 2000, Litvin \& Weinstein 2003, 2004, Weinstein et al. 2005), especially where ponds are embedded in marshes (e.g. Goodyear or Denverton sloughs; Fig. 6B).

Overall, our study shows that tidal marsh habitats in the San Francisco Estuary, California, can be important nursery areas for fishes with diverse life histories, and that the most productive and resilient habitats have physically and ecologically complex characteristics and are hydrologically connected to adjacent terrestrial habitats. Our findings may apply 
Fig. 6. Conceptual model of the Suisun Marsh estuarine-terrestrial gradient, which facilitates diverse physical and ecological processes at the seascape-landscape interface and supports nursery hotspots for fishes with different life histories. The transition from open-water-dominated to landdominated habitats, including deep and shallow sloughs, tidal marshes, managed tidal ponds, and uplands, represents a habitat continuum that provides abundant opportunities for foraging and refuge across a range of environmental and flow conditions. (A) Historic tidal marsh-upland gradients consistently function as nursery hotspots and serve as idealized models for habitat restoration. (B) Novel tidal marshpond-upland gradients are also nursery hotspots and offer alternative models aimed to enhance fish recruitment in altered landscapes/seascapes. Image credit: Emily Damstra

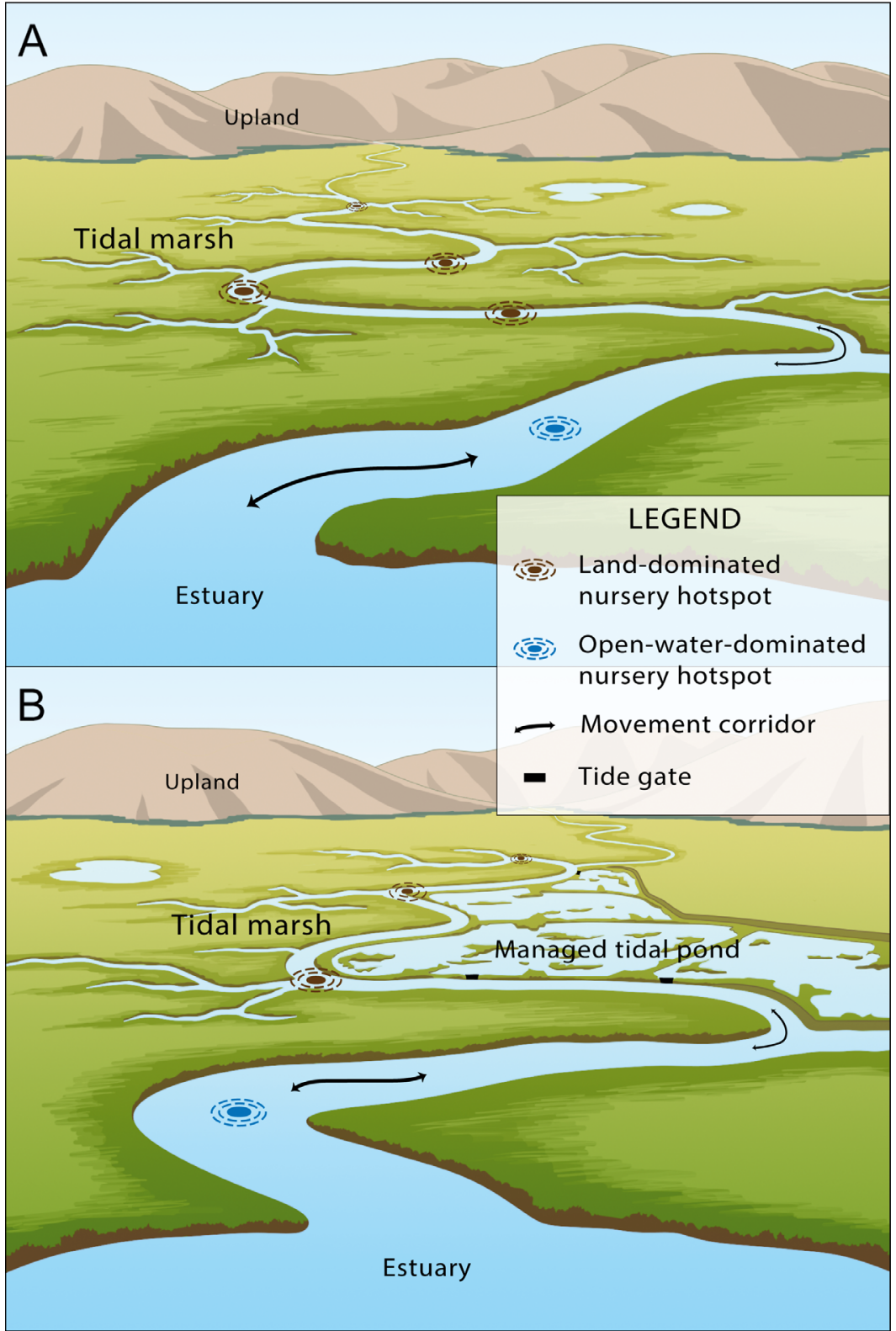

to ecological gradients in other marine systems, but their application is most appropriate for drowned river valley estuaries with topographic heterogeneity and small upland watersheds draining into marshes. Conservation and management of estuarine fishes will depend on improved understanding of these ecosystems, and on synthesis of long-term data that track responses of fish assemblages to natural and anthropogenic stressors and to restoration of habitat heterogeneity within the estuarine habitat mosaic.

Acknowledgements. Surveys were conducted by faculty, staff, students, and volunteers as part of the University of California, Davis, Suisun Marsh Fish Study (https://water shed.ucdavis.edu/project/suisun-marsh-fish-study). Funding was provided by the Department of Water Resources (Grant no. 4600011551), the California Department of Fish and Wildlife Proposition 1 (Grant no. P1696010) and the S. D. Bechtel, Jr. Foundation. Additional funding for D.D.C. was provided by a Delta Science Fellowship (Grant no. 2271) administered by the Delta Science Program and California Sea Grant. Fig. 6 illustration by Emily Damstra. We thank Matthew Young, Christina Toms, and 3 helpful anonymous reviewers for improving the manuscript.

\section{LITERATURE CITED}

Baltz DM, Moyle PB (1982) Life history characteristics of tule perch (Hysterocarpus traski) populations in contrasting environments. Environ Biol Fishes 7:229-242 
Baumsteiger J, Schroeter RE, O'Rear T, Cook JD, Moyle PB (2017) Long-term surveys show invasive overbite clams (Potamocorbula amurensis) are spatially limited in Suisun Marsh, California. San Francisco Estuar Watershed Sci 15:6

Beck MW, Heck KL, Able KW, Childers DL and others (2001) The identification, conservation, and management of estuarine and marine nurseries for fish and invertebrates: a better understanding of the habitats that serve as nurseries for marine species and the factors that create sitespecific variability in nursery quality will improve conservation and management of these areas. Bioscience 51: 633-641

Beller EE, Spotswood EN, Robinson AH, Anderson MG and others (2019) Building ecological resilience in highly modified landscapes. BioScience 69:80-92

Boesch DF, Turner RE (1984) Dependence of fishery species on salt marshes: the role of food and refuge. Estuaries 7 : 460-468

* Boström C, Pittman SJ, Simenstad C, Kneib RT (2011) Seascape ecology of coastal biogenic habitats: advances, gaps, and challenges. Mar Ecol Prog Ser 427:191-217

Bürkner PC (2017) brms: an R package for Bayesian multilevel models using Stan. J Stat Softw 80:1-28

Bürkner PC (2018) Advanced Bayesian multilevel modeling with the R package brms. R J 10:395-411

Buuren SV, Groothuis-Oudshoorn K (2011) mice: multivariate imputation by chained equations in R. J Stat Softw 45:1-68

CalAtlas (2012) California Geospatial Clearinghouse: highways, railroads, California state boundary. State of California. http://atlas.ca.gov/ (accessed June 2012)

Dahlgren CP, Eggleston DB (2000) Ecological processes underlying ontogenetic habitat shifts in a coral reef fish. Ecology 81:2227-2240

Enright C, Culberson SD, Burau JR (2013) Broad timescale forcing and geomorphic mediation of tidal marsh flow and temperature dynamics. Estuar Coast 36:1319-1339

Fagherazzi S, Anisfeld SC, Blum LK, Long EV and others (2019) Sea level rise and the dynamics of the marshupland boundary. Front Environ Sci 7:25

Feyrer F, Sommer TR, Baxter RD (2005) Spatial-temporal distribution and habitat associations of age-0 splittail in the lower San Francisco Estuary watershed. Copeia 2005: 159-168

Feyrer F, Hobbs J, Sommer T (2010) Salinity inhabited by age-0 splittail (Pogonichthys macrolepidotus) as determined by direct field observation and retrospective analyses with otolith chemistry. San Francisco Estuar Watershed Sci 8:1-10

Fox J, Weisberg S (2018) An R companion to applied regression. Sage Publications, Thousand Oaks, CA

Gabry J, Mahr T (2019) bayesplot: plotting for Bayesian models. $\mathrm{R}$ package version 1.7.0. https://mc-stan.org/ bayesplot/

Gesch D, Oimoen M, Greenlee S, Nelson C, Steuck M, Tyler D (2002) The national elevation dataset. Photogramm Eng Remote Sensing 68:5-32

Goals Project (2015) The baylands and climate change: what we can do. Baylands ecosystem habitat goals science update 2015 prepared by the San Francisco Bay Area Wetlands Ecosystem Goals Project. California State Coastal Conservancy, Oakland, CA

Grol MG, Nagelkerken I, Rypel AL, Layman CA (2011) Simple ecological trade-offs give rise to emergent crossecosystem distributions of a coral reef fish. Oecologia 165:79-88

Gunter G (1967) Some relationships of estuaries to the fish- eries of the Gulf of Mexico. American Association for the Advancement of Science, Washington, DC

*Hammock BG, Hartman R, Slater SB, Hennessy A, Teh SJ (2019) Tidal wetlands associated with foraging success of delta smelt. Estuar Coast 42:857-867

Hay WP (1905) The life history of the blue crab (Callinectes sapidus) (No. 580). US Government Printing Office, Washington, DC

*Hitchman SM, Mather ME, Smith JM, Fencl JS (2018) Identifying keystone habitats with a mosaic approach can improve biodiversity conservation in disturbed ecosystems. Glob Change Biol 24:308-321

Hoffman MD, Gelman A (2014) The No-U-Turn sampler: adaptively setting path lengths in Hamiltonian Monte Carlo. J Mach Learn Res 15:1593-1623

Hughes BB, Levey MD, Brown JA, Fountain MC and others (2014) Nursery functions of US West Coast estuaries: the state of knowledge for juveniles of focal invertebrate and fish species. Nature Conservancy, Arlington, VA

Kimmerer WJ, Gross ES, MacWilliams ML (2009) Is the response of estuarine nekton to freshwater flow in the San Francisco Estuary explained by variation in habitat volume? Estuar Coast 32:375

Kirwan ML, Walters DC, Reay WG, Carr JA (2016) Sea level driven marsh expansion in a coupled model of marsh erosion and migration. Geophys Res Lett 43:4366-4373

Kneib RT (1997) The role of tidal marshes in the ecology of estuarine nekton. Oceanogr Mar Biol Annu Rev 35: $163-220$

Lankford TE, Targett TE (1994) Suitability of estuarine nursery zones for juvenile weakfish (Cynoscion regalis): effects of temperature and salinity on feeding, growth and survival. Mar Biol 119:611-620

Levin LA, Boesch DF, Covich A, Dahm C and others (2001) The function of marine critical transition zones and the importance of sediment biodiversity. Ecosystems 4(5): $430-451$

*Litvin SY, Weinstein MP (2003) Life history strategies of estuarine nekton: the role of marsh macrophytes, benthic microalgae, and phytoplankton in the trophic spectrum. Estuaries 26:552-562

Litvin SY, Weinstein MP (2004) Multivariate analysis of stable-isotope ratios to infer movements and utilization of estuarine organic matter by juvenile weakfish (Cynoscion regalis). Can J Fish Aquat Sci 61:1851-1861

* Litvin SY, Weinstein MP, Sheaves M, Nagelkerken I (2018) What makes nearshore habitats nurseries for nekton? An emerging view of the nursery role hypothesis. Estuar Coasts 41:1539-1550

Manfree AD (2014) Landscape change in Suisun Marsh. $\mathrm{PhD}$ dissertation, University of California, Davis, CA

Marani M, Belluco E, Ferrari S, Silvestri S and others (2006) Analysis, synthesis and modelling of high-resolution observations of salt-marsh eco-geomorphological patterns in the Venice lagoon. Estuar Coast Shelf Sci 69:414-426

* Matern SA, Moyle PB, Pierce LC (2002) Native and alien fishes in a California estuarine marsh: twenty-one years of changing assemblages. Trans Am Fish Soc 131:797-816

McElreath R (2018) Statistical rethinking: a Bayesian course with examples in R and Stan. Chapman and Hall/CRC, Boca Raton, FL

*McIvor CC, Odum WE (1988) Food, predation risk, and microhabitat selection in a marsh fish assemblage. Ecology 69:1341-1351

* Meng L, Matern SA (2001) Native and introduced larval fishes of Suisun Marsh, California: the effects of freshwater flow. Trans Am Fish Soc 130:750-765 
Meng L, Moyle PB, Herbold B (1994) Changes in abundance and distribution of native and introduced fishes of Suisun Marsh. Trans Am Fish Soc 123:498-507

Montgomery JR (2017) Foodweb dynamics in shallow tidal sloughs of the San Francisco Estuary. MSc thesis, University of California, Davis, CA

Moyle PB (2002) Inland fishes of California: revised and expanded. University of California Press, Berkeley, CA

Moyle PB (2014) Novel aquatic ecosystems: the new reality for streams in California and other Mediterranean climate regions. River Res Appl 30:1335-1344

Moyle PB, Baxter RD, Sommer T, Foin TC, Matern SA (2004) Biology and population dynamics of Sacramento splittail (Pogonichthys macrolepidotus) in the San Francisco Estuary: a review. San Francisco Estuar Watershed Sci 2:1-48

Moyle PB, Manfree AD, Fiedler PL (eds) (2014) Suisun Marsh: ecological history and possible futures. University of California Press, Berkeley, CA

Munsch SH, Cordell JR, Toft JD (2016) Fine-scale habitat use and behavior of a nearshore fish community: nursery functions, predation avoidance, and spatiotemporal habitat partitioning. Mar Ecol Prog Ser 557:1-15

Nagelkerken I, Sheaves M, Baker R, Connolly RM (2015) The seascape nursery: a novel spatial approach to identify and manage nurseries for coastal marine fauna. Fish Fish 16:362-371

Odum WE (1984) Dual-gradient concept of detritus transport and processing in estuaries. Bull Mar Sci 35:510-521

Oksanen J, Blanchet FG, Friendly M, Kindt R and others (2018) vegan: Community Ecology Package. R package version 2.5.2. https://github.com/vegandevs/vegan

Oleson KL, Falinski KA, Audas DM, Coccia-Schillo S, Groves P, Teneva L, Pittman SJ (2017) Linking landscape and seascape conditions: science, tools and management. Seascape Ecology. Wiley and Sons, London

Pedersen EJ, Miller DL, Simpson GL, Ross N (2019) Hierarchical generalized additive models in ecology: an introduction with mgcv. PeerJ 7:e6876

R Core Team (2018) R: a language and environment for statistical computing. R Foundation for Statistical Computing, Vienna

Robertson AI, Duke NC (1990) Recruitment, growth and residence time of fishes in a tropical Australian mangrove system. Estuar Coast Shelf Sci 31:723-743

Rosenzweig ML (2003) Reconciliation ecology and the future of species diversity. Oryx 37:194-205

Rountree RA, Able KW (2007) Spatial and temporal habitat use patterns for salt marsh nekton: implications for ecological functions. Aquat Ecol 41:25-45

Rozas LP, McIvor CC, Odum WE (1988) Intertidal rivulets and creekbanks: corridors between tidal creeks and marshes. Mar Ecol Prog Ser 47:303-307

San Francisco Estuary Institute (SFEI) (2012) Bay Area EcoAtlas. Modern baylands. www.sfei.org/ecoatlas/ (accessed June 2012)

Schile LM, Callaway JC, Morris JT, Stralberg D, Parker VT, Kelly M (2014) Modeling tidal marsh distribution with sea-level rise: evaluating the role of vegetation, sediment, and upland habitat in marsh resiliency. PLOS ONE 9:e88760

Scofield EC (1931) The striped bass of California (Roccus saxatilis). Calif Div Fish Game Fish Bull 29:1-84

Editorial responsibility: Elliott Hazen,

Pacific Grove, California, USA
Shafer DJ, Streever WJ (2000) A comparison of 28 natural and dredged material salt marshes in Texas with an emphasis on geomorphological variables. Wetlands Ecol Manag 8:353-366

Simenstad CA, Burke JL, O'Connor JE, Cannon C and others (2011) Columbia River estuary ecosystem classification concept and application (No. 2011-1228). US Geological Survey, Reston, VA

Sogard SM (1997) Size-selective mortality in the juvenile stage of teleost fishes: a review. Bull Mar Sci 60:1129-1157

* Sommer T, Baxter R, Herbold B (1997) Resilience of splittail in the Sacramento-San Joaquin estuary. Trans Am Fish Soc 126:961-976

* Sommer T, Mejia F, Hieb K, Baxter R, Loboschefsky E, Loge F (2011) Long term shifts in the lateral distribution of age 0 striped bass in the San Francisco Estuary. Trans Am Fish Soc 140:1451-1459

Stan Development Team (2018) RStan: the R interface to Stan. R package version 2.18.2. https://mc-stan.org/users/ interfaces/rstan.html

Teal JM, Weinstein MP (2002) Ecological engineering, design, and construction considerations for marsh restorations in Delaware Bay, USA. Ecol Eng 18:607-618

US Geological Survey (2004) National hydrography dataset. https://www.usgs.gov/core-science-systems/ngp/ national-hydrography/national-hydrography-dataset (accessed January 2019)

Vehtari A, Bürkner P, Gabry J (2018) Leave-one-out crossvalidation for non-factorizable models. Tech Rep. http:// mc-stan.org/loo/articles/loo2-non-factorizable.html (accessed March 2019)

Visintainer TA, Bollens SM, Simenstad C (2006) Community composition and diet of fishes as a function of tidal channel geomorphology. Mar Ecol Prog Ser 321:227-243

Weinstein MP, Kreeger DA (eds) (2000) Concepts and controversies in tidal marsh ecology. Springer Science \& Business Media, Dordrecht

Weinstein MP, Teal JM, Balletto JH, Strait KA (2001) Restoration principles emerging from one of the world's largest tidal marsh restoration projects. Wetlands Ecol Manag 9:387-407

Weinstein MP, Litvin SY, Guida VG (2005) Considerations of habitat linkages, estuarine landscapes, and the trophic spectrum in wetland restoration design. J Coast Res 21: 51-63

Weinstein MP, Litvin SY, Krebs JM (2014) Restoration ecology: ecological fidelity, restoration metrics, and a systems perspective. Ecol Eng 65:71-87

Whitcraft CR, Grewell BJ, Baye PR (2011) Estuarine vegetation at Rush Ranch Open Space Preserve, San Francisco Bay National Estuarine Research Reserve, California. San Francisco Estuar Watershed Sci 9:1-29

Wood SN (2003) Thin plate regression splines. J R Stat Soc Ser B Stat Methodol 65:95-114

* Young MJ, Feyrer FV, Colombano DD, Conrad JL, Sih A (2018) Fish-habitat relationships along the estuarine gradient of the Sacramento-San Joaquin Delta, California: implications for habitat restoration. Estuar Coast 41: 2389-2409

Zuur A, Ieno EN, Walker N, Saveliev AA, Smith GM (2009) Mixed effects models and extensions in ecology with R. Springer Science \& Business Media, New York, NY

Submitted: April 15, 2019; Accepted: January 15, 2020 Proofs received from author(s): February 21, 2020 